René J. Raggers · Ilse Vogels • Gerrit van Meer

\title{
Upregulation of the expression of endogenous Mdr1 P-glycoprotein enhances lipid translocation in MDCK cells transfected with human MRP2
}

Accepted: 26 October 2001 / Published online: 30 November 2001 (C) Springer-Verlag 2001

\begin{abstract}
Various ABC transporters can translocate lipid molecules from the cytoplasmic into the exoplasmic leaflet of the plasma membrane bilayer. Two of these, MDR1 P-glycoprotein (Pgp) and MRP1, are multidrug transporters responsible for the resistance of various cancers against chemotherapy. We wanted to study whether MRP2, an ABC transporter of the bile canalicular membrane with a substrate specificity very similar to that of MRP1, is capable of translocating lipids. The translocation of short-chain lipids across the apical membrane of MDCK cells transfected with MRP2 was significantly higher than that in untransfected controls. However, the characteristics of the lipid translocation were similar to substrate transport by MDR1 and not MRP2: transport was strongly inhibited by classic MDR1 Pgp inhibitors, was independent of cellular glutathione, and was insensitive to a drug known to inhibit MRP2 activity. When tested by immunoblot, the MRP2-transfected cells expressed high levels of MRP2 but also of endogenous Mdr1. The expression of Mdr1 was unstable during maintenance of the cell line and correlated with the rate of lipid translocation across the apical membrane. We conclude that the observed increase in lipid transport in the MDCK cells transfected with MRP2 is the consequence of the upregulation of the expression of endogenous Mdr1 and that careful characterization of endoge-
\end{abstract}

G. van Meer (

University of Amsterdam,

Department of Cell Biology and Histology,

Academic Medical Center, Meibergdreef 15,

1105 AZ Amsterdam, The Netherlands

e-mail: g.vanmeer@amc.uva.nl

Tel.: +31-20-5664965, Fax: +31-20-7469156

R.J. Raggers · I. Vogels · G. van Meer

Department of Cell Biology and Histology,

Academic Medical Center, University of Amsterdam,

P.O. Box 22700, 1100 DE Amsterdam, The Netherlands

Present address:

R.J. Raggers, Numico Research B.V., Postbus 7005,

6700 CA Wageningen, The Netherlands nous Mdr1 expression is needed in studies aimed to identify substrates of plasma membrane transporters.

Keywords $\mathrm{ABC}$ transporters $\cdot$ Multidrug transporters . Lipids · Translocation · MDCK cells

\section{Introduction}

It has been suggested that the energy needed to drive endocytosis is provided by the aminophospholipid translocator (Farge et al. 1999). Under consumption of ATP this protein moves (aminophospho)lipid molecules from the outer leaflet of the plasma membrane bilayer into the cytosolic leaflet, and the resulting increase in the lateral pressure of the inner vs the outer leaflet would generate the force needed for inward budding of vesicles. Over the last 5 years, various ATP-binding cassette (ABC) transporters have been identified as lipid flippases in the opposite direction (see Borst et al. 2000; Raggers et al. 2000). Two of these are the human multidrug resistance protein MRP1 and the MDR1 P-glycoprotein (Pgp) that actively transport a wide range of compounds across membranes out of the cytosol. MRP1 and MDR1 Pgp are highly expressed in a number of cancer cells, where they oppose chemotherapy by pumping drugs out of the cells (Gottesman and Pastan 1993). The drugs transported by MRP1 and MDR1 Pgp have in common that they have an amphipathic character. Over the past decade, it has been demonstrated that MRP1 and MDR1 Pgp, and a number of other $\mathrm{ABC}$ transporters, translocate analogs of membrane lipids across the bilayer. A fluorescent analog of the glycosphingolipid glucosylceramide $\left(\mathrm{C}_{6}\right.$ NBD-GlcCer) is a substrate for both proteins. However, $\mathrm{C}_{6}$-NBD-phosphatidylcholine $\left(\mathrm{C}_{6}\right.$-NBD-PC) was exclusively transported by MDR1 Pgp. Whereas lipid transport by MRP1 was sensitive to MRP1 inhibitors such as indomethacin and depended on glutathione (Raggers et al. 1999), this was not the case for lipid translocation by MDR1 Pgp. The latter transport was selectively sensitive to MDR1 inhibitors such as PSC833 and verapamil (van Helvoort et al. 1996; Bosch et al. 1997). 


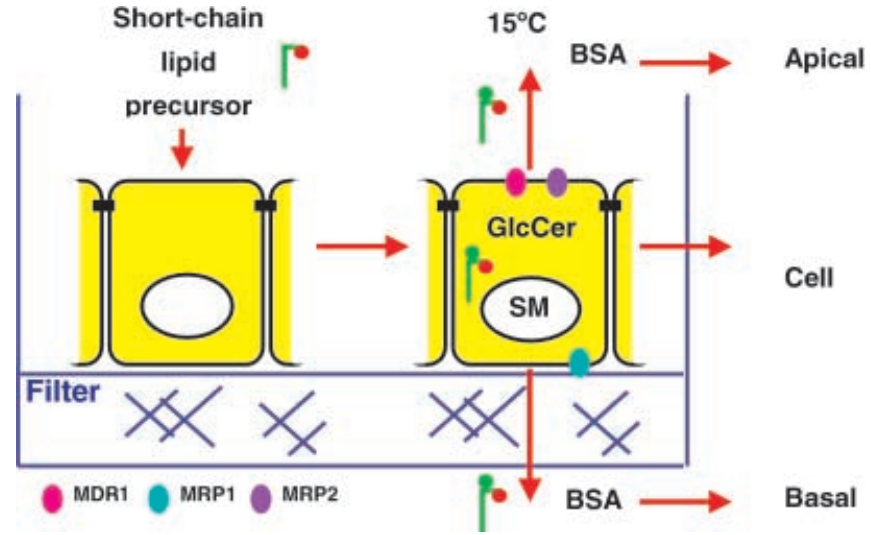

Fig. 1 Assay for lipid translocation across the plasma membrane. A short-chain lipid precursor, $\mathrm{C}_{6}-\mathrm{NBD}$-ceramide or $\mathrm{C}_{6}-\mathrm{NBD}$ phosphatidic acid, is added to a confluent monolayer of MadinDarby canine kidney (MDCK) cells on a permeable support. The cells had been transfected with either MDR1 P-glycoprotein (Pgp), MRP1, or MRP2. The cells are incubated for $3 \mathrm{~h}$ at $15^{\circ} \mathrm{C}$ in the presence of serum albumin (BSA) both in the apical medium in the filter cup and in the basolateral medium underneath the filter. Any newly synthesized short-chain fluorescent lipid product that reaches the cell surface is trapped by the BSA. Finally, the fluorescent lipids in media and cells are quantitatively analyzed. GlcCer Glucosylceramide, $S M$ sphingomyelin

MRP2 belongs to the $A B C C$-gene family (ABCC2) and shows $49 \%$ amino acid sequence identity with MRP1 (ABCC1; Keppler et al. 1997). While MRP1 is detected in the plasma membrane of many cell types, including erythrocytes, and is limited to the basolateral membrane of polarized cells like other types of transporter proteins (Sugawara-Yokoo et al. 2000), MRP2 has been localized to apical domains, and particularly to the hepatocyte canalicular membrane like other transporter proteins in other cell types (Haila et al. 2000). MRP1 and MRP2 display highly overlapping substrate specificities, including physiologically important glutathione $S$ conjugates such as leukotriene $\mathrm{C} 4$, bilirubin glucuronides, and glutathione disulfide (Keppler et al. 1997). They have a common, but not identical, sensitivity to indomethacin and glutathione depletion (Bakos et al. 2000; Evers et al. 2000). MRP2 is deficient in Dubin-Johnson syndrome (Paulusma et al. 1996), which is therefore associated with an inherited deficiency in the secretion of amphiphilic anionic conjugates into the bile of these patients.

In order to study whether MRP2, like MRP1, is capable of moving short-chain lipids across the plasma membrane, we made use of Madin-Darby canine kidney (MDCK) strain II cells transfected with human MRP2 cDNA, in which MRP2 has been shown to be located in the apical membrane (Evers et al. 1998, 2000). The cells were allowed to synthesize $\mathrm{C}_{6}$-NBD-lipids from exogenously added precursors, and transport to the outer leaflet of the plasma membrane was studied as before (Fig. 1; van Helvoort et al. 1996; Raggers et al. 1999). Transfection of MDCK II cells with human MRP2 enhanced transport of $\mathrm{C}_{6}$-NBD-GlcCer and $\mathrm{C}_{6}$-NBD-PC across the apical membrane of these cells. However, the increase in transport appears to be the consequence of the upregulation of endogenous Mdr1 expression and is independent of MRP2, as shown by an analysis of the expression of both proteins and of the drug sensitivity of the observed transport.

\section{Materials and methods}

\section{Materials}

D,L-Buthionine $[\mathrm{S}, \mathrm{R}]$-sulfoximine (BSO), bovine serum albumin fraction V (BSA), and glutathione ethyl ester were purchased from Sigma (St. Louis, Mo., USA). Indomethacin was from ICN (Aurora, Ohio, USA), and PSC833 was a kind gift of Novartis (Basel, Switzerland). $\mathrm{C}_{6}$-NBD-ceramide was from Molecular Probes (Eugene, Ore., USA). $\mathrm{C}_{6}$-NBD-phosphatidic acid ( $\mathrm{C}_{6}$-NBD-PA) was from Avanti Polar Lipids (Alabaster, Ala., USA). Organic solvents and silica TLC plates were from Merck (Darmstadt, Germany) and cell culture media from Gibco (Paisley, UK).

\section{Cell culture}

MDCK II cells transfected with MRP1 (Evers et al. 1997), with MRP2 (Evers et al. 1998), clone MRP227, and with MDR1 Pgp were a kind gift of Dr. S. Smith. Cells were cultured (mycoplasma-free) in MEM/10 mM HEPES, as in Pomorski et al. (1999), but supplemented with 5\% FCS. For experiments $2 \times 10^{6}$ cells on $4.7 \mathrm{~cm}^{2}$ Transwells (Costar, Cambridge, Mass., USA) were grown as monolayers for 3-5 days.

\section{Transport incubations}

The precursors $\mathrm{C}_{6}$-NBD-ceramide and $\mathrm{C}_{6}$-NBD-PA were added to MDCK cell monolayers and transport of $\mathrm{C}_{6}-\mathrm{NBD}-\mathrm{GlcC}$ er and $\mathrm{C}_{6}-$ NBD-PC, respectively, to the apical and basolateral surface were measured after $3 \mathrm{~h}$ at $15^{\circ} \mathrm{C}$ as before, using BSA depletion from the surface, lipid extraction, two-dimensional TLC, and fluorescence quantitation (van Helvoort et al. 1996; Raggers et al. 1999). Inhibitors were added $10 \mathrm{~min}$ before the start of the transport incubation. Glutathione depletion was carried out as before (Raggers et al. 1999).

\section{Western blots}

The levels of MDR1 Pgp and MRP2 were determined in total cell lysates. For this, $80 \mu \mathrm{g}$ protein was size-separated on a $10 \%(\mathrm{w} / \mathrm{v})$ polyacrylamide gel containing $0.1 \%$ SDS (w/v). After electroblotting to nitrocellulose, MDR1 Pgp was visualized by using monoclonal antibody JSB1 or C219 [kind gifts of Dr. R. Schepers (Free University, Amsterdam)] and MRP2 was visualized by staining with monoclonal antibody M2-III-6 (a kind gift from Dr. R. Oude Elferink, University of Amsterdam). Bands were visualized by the enhanced chemiluminescence procedure (Amersham) using Kodak BioMax MS X-ray films.

\section{Results and discussion}

Translocation of $\mathrm{C}_{6}$-NBD-GlcCer by MDCK-MRP2 cells

$\mathrm{C}_{6}$-NBD-GlcCer has been found to be a substrate for translocation by both MDR1 Pgp (van Helvoort et al. 1996) and MRP1 (Raggers et al. 1999). In these studies, 
Table 1 Transport of $\mathrm{C}_{6}$-NBD-lipids to the surface of Madin-Darby canine kidney $(M D C K)$ cells at $15^{\circ} \mathrm{C}$. Cells were incubated with $5 \mu \mathrm{M} \mathrm{C}_{6}$-NBD-ceramide, as a precursor for glucosylceramide (GlcCer) and sphingomyelin (SM), or with $25 \mu \mathrm{M} \mathrm{C}_{6}$-NBD-phosphatidic acid, as a precursor for phosphatidylcholine $(P C)$ and phosphatidylethanolamine $(P E)$, during $3 \mathrm{~h}$ at $15^{\circ} \mathrm{C}$, after which the cell surface was washed free of NBD-lipids. The lipids in the combined media and washes were analyzed and quantified. Transport is expressed as the percentage of each fluorescent lipid recov- ered in apical or basolateral medium. In all cell lines, roughly $5 \%$ of the newly synthesized $\mathrm{C}_{6}-\mathrm{NBD}-\mathrm{SM}$ was recovered in the apical medium, and dependent on the cell line $15-30 \%$ was recovered in the basolateral medium. The latter and the PC in the basolateral medium are the result of synthesis on the basolateral cell surface (van Helvoort et al. 1994). Numbers are followed by the standard deviation, and the number of measurements is in parentheses. [ND $\mathrm{C}_{6}$-NBD-PC and $\mathrm{C}_{6}$-NBD-PE are not translocated by MRP1 (Raggers et al. 1999) and this was not further studied here]

\begin{tabular}{|c|c|c|c|c|c|c|}
\hline & \multicolumn{2}{|c|}{$\mathrm{C}_{6}$-NBD-GlcCer (\%) } & \multicolumn{2}{|c|}{$\mathrm{C}_{6}$-NBD-PC (\%) } & \multicolumn{2}{|c|}{$\mathrm{C}_{6}$-NBD-PE (\%) } \\
\hline & Apical & Basolateral & Apical & Basolateral & Apical & Basolateral \\
\hline MDCK II & $3 \pm 2(9)$ & $3 \pm 2(9)$ & $3 \pm 2(4)$ & $65 \pm 10(4)$ & $2 \pm 1(6)$ & $1 \pm 1(6)$ \\
\hline MDCK-MRP1 & $3 \pm 1(6)$ & $30 \pm 13(6)$ & $\mathrm{ND}$ & ND & & \\
\hline MDCK-MRP2 & $25 \pm 10$ & $6 \pm 4$ (14) & $15 \pm 2(4)$ & $41 \pm 5(4)$ & $23 \pm 13$ (4) & $6 \pm 2(4)$ \\
\hline MDCK-MDR1 & $28 \pm 10(9)$ & $5 \pm 2(9)$ & $15 \pm 3(4)$ & $43 \pm 12(4)$ & $28 \pm 18$ (4) & $5 \pm 3(4)$ \\
\hline
\end{tabular}

a confluent monolayer of epithelial LLC PK1 cells was incubated with $\mathrm{C}_{6}-\mathrm{NBD}$-ceramide for $3 \mathrm{~h}$ at $15^{\circ} \mathrm{C}$. Because of its short acyl chain $\mathrm{C}_{6}$-NBD-ceramide diffuses across aqueous phases and because it has no polar headgroup it rapidly crosses membranes. Thus, $\mathrm{C}_{6}-\mathrm{NBD}-$ ceramide reaches the Golgi where it is converted to $\mathrm{C}_{6}$ NBD-GlcCer on the cytosolic surface and to $\mathrm{C}_{6}$-NBDsphingomyelin $(\mathrm{SM})$ in the lumen. Consequently, $\mathrm{C}_{6}$ NBD-GlcCer can equilibrate with the cytosolic surface of the plasma membrane (Jeckel et al. 1992; van Helvoort et al. 1996). When $\mathrm{C}_{6}$-NBD-GlcCer is translocated across the plasma membrane to the exoplasmic leaflet, it is extracted by BSA in the apical or basolateral medium which binds this short-chain lipid and acts as a sink. $\mathrm{C}_{6}-\mathrm{NBD}-\mathrm{SM}$ is sequestered in the lumen of the Golgi and has no access to the cytosolic surface of the plasma membrane. Arrival of $\mathrm{C}_{6}-\mathrm{NBD}-\mathrm{GlcCer}$ on the surface by exchange through the cytosol and translocation is discriminated from delivery to the plasma membrane via vesicular transport by the incubation conditions. At $15^{\circ} \mathrm{C}$ the traffic of membrane vesicles, but not aqueous transfer and translocation, is blocked.

In order to test whether MRP2 is capable of translocating short-chain lipids across the plasma membrane, we first tested $\mathrm{C}_{6}$-NBD-GlcCer as a substrate for translocation in MDCK II cells stably transfected with MRP2. MDCK-MDR1 and MDCK-MRP1 were included as positive controls and untransfected MDCK II cells as a negative control. After the transport assay, more of the newly synthesized $\mathrm{C}_{6}$-NBD-GlcCer was recovered in the apical medium of MDCK-MDR1 cells and in the basolateral medium of MDCK-MRP1 cells than in the media of MDCK II control cells (Table 1) which is in accordance with the published data for transfected LLC PK1 cells. In addition, more $\mathrm{C}_{6}$-NBD-GlcCer was found in the apical medium of MDCK-MRP2 cells than in the control, whereas the percentage found in the basal medium was similar. This suggests that MRP2 translocated $\mathrm{C}_{6}$-NBDGlcCer across the apical membrane, which would fit the localization of MRP2 to the apical membrane of the MDCK-MRP2 cells (Evers et al. 1998).
Substrate specificity in MDCK-MRP2 cells

$\mathrm{C}_{6}$-NBD-PC and $\mathrm{C}_{6}$-NBD-phosphatidylethanolamine $\left(\mathrm{C}_{6}\right.$-NBD-PE) have been found to be substrates for translocation by MDR1 Pgp (van Helvoort et al. 1996), but not MRP1 (Raggers et al. 1999). When transport of $\mathrm{C}_{6}$ NBD-PC and $\mathrm{C}_{6}$-NBD-PE was measured in MDCKMRP2, clearly, both lipids were translocated across the apical surface of these cells (Table 1). This was unexpected since the substrate specificity of MRP1 and MRP2 is very similar. The activity in MDCK-MRP2 cells resembled that of MDCK-MDR1.

\section{Inhibitor sensitivity in MDCK-MRP2 cells}

The difference in substrate specificity between MDR1 Pgp and MRP1 is also illustrated by their different sensitivities to inhibitors. Whereas MDR1 Pgp is typically inhibited by verapamil, cyclosporin, and PSC 833 , MRP1 is insensitive to these drugs but is sensitive to indomethacin. Verapamil, cyclosporin, and PSC833 inhibited transport of $\mathrm{C}_{6}$-NBD-GlcCer toward the apical surface of MDCK-MRP2 cells by $87 \%(n=2)$, by $94 \%$ $(n=4)$, and $98 \%(n=4)$, respectively. Transport toward the basolateral surface was inhibited by $70-90 \%$ by the respective inhibitors. This most likely reflects the fact that the small increase of basolateral transport as compared to the control is due to missorting of a small fraction of the apical translocator (cf. van Helvoort et al. 1996). Indomethacin had no effect on $\mathrm{C}_{6}$-NBD-GlcCer transport toward the apical medium (103\% of control MDCKMRP2) and inhibited basolateral transport by $30 \%$ suggesting that basolateral transport is partially due to endogenous Mrp1. Overall, the inhibition profile of lipid translocation in MDCK-MRP2 cells resembled that of MDR1 Pgp not MRP1.

Glutathione is a substrate for both MRP1 and MRP2 and free glutathione greatly stimulates transport of substrates that are not covalently attached to glutathione. Glutathione depletion reduced lipid translocation by 
MRP1 but not by MDR1 Pgp (Raggers et al. 1999). Basolateral transport of $\mathrm{C}_{6}$-NBD-GlcCer in MDCK-MRP1 cells was only $13 \%$ in $3 \mathrm{~h}$ at $15^{\circ} \mathrm{C}$ after glutathione depletion by $24 \mathrm{~h}$ preincubation with $25 \mu \mathrm{M}$ BSO, as compared to $29 \%$ in the presence of BSO plus glutathione ethyl ester (which restores the glutathione level; $n=2$ ). In contrast, BSO treatment had essentially no effect on apical transport in MDCK-MRP2 (93\% of the control), while addition of glutathione ethyl ester lowered this number further to $77 \%$ instead of correcting the effect of BSO. Lipid translocation in MDCK-MRP2 appeared independent of glutathione, which further argues against a role for MRP2 in the translocation event.

Lipid translocation in MDCK II cells is unstable during cell culture

The MDCK-MRP2 cells displayed a stable level of $\mathrm{C}_{6}$ NBD-GlcCer translocation, $25 \%$ during $3 \mathrm{~h}$ at $15^{\circ} \mathrm{C}$, for 3 months, when over a period of several weeks the translocation went down to $9 \pm 1 \%(n=6)$. In addition, we observed at a different point in time that the $\mathrm{C}_{6}$-NBD-GlcCer translocation in the control MDCK II cells rose from a level of $3 \%$ to a new stable level of $10 \pm 1 \%(n=4)$ over a period of weeks. Finally, we measured that the $\mathrm{C}_{6}$ NBD-GlcCer translocation activity depended on the number of days in culture. After 9 days in culture, $\mathrm{C}_{6}$ NBD-GlcCer translocation over the apical surface of MDCK II cells and MDCK-MRP2 cells was 2 times higher than after 2 days in culture $(n=3)$. In one experiment, the $\mathrm{C}_{6}$-NBD-GlcCer translocation in control MDCK II cells rose to $22 \%(n=2$, range $1 \%)$ in $3 \mathrm{~h}$ at $15^{\circ} \mathrm{C}$. Because these phenomena were observed in MDCK II, MDCK-MRP1, and in MDCK-MRP2 cells, we concluded that the variable expression of one common translocator might be the cause of the variation in translocation activity.

Endogenous Mdr1 expression is upregulated in MRP2-transfected MDCK II cells

In order to establish whether possibly endogenous Mdr1 was upregulated in the MDCK-MRP2 cells, the cellular proteins were separated by SDS-PAGE, transferred to nitrocellulose, and blotted with the anti-MRP2 monoclonal antibody M2-III-6 and with the anti-MDR1 Pgp antibody. We included the MDCK-MRP2 line that had a strongly reduced ability to translocate $\mathrm{C}_{6}$-NBD-GlcCer ("inactive" MDCK-MRP2). As shown in Fig. 2, both MDCK-MRP2 lines abundantly express MRP2, whereas the protein was absent from MDCK II control cells and from MDCK-MDR1. Since the MDCK-MRP2 cells in lane 2 had lost the capability to translocate $\mathrm{C}_{6}$-NBD-GlcCer, the presence of MRP2 did not correlate with translocation activity. In contrast, the anti-MDR1 antibody recognized human MDR1 Pgp in the MDCK-MDR1 cells, but also yielded a marked signal in MDCK II and
Fig. 2 Blot of MDCK proteins with antibodies against MRP2 and MDR1 Pgp. Total proteins of MDCK II control cells (lane 1), MDCK-MRP2 cells, "inactive" in translocation (lane 2), MDCK-MRP2 cells, "active" in translocation (lane 3), and MDCK-MDR1 cells (lane 4) were separated on a $10 \%$ SDS gel, and western blotting was performed using anti-MRP2 and antiMDR1 Pgp antibodies

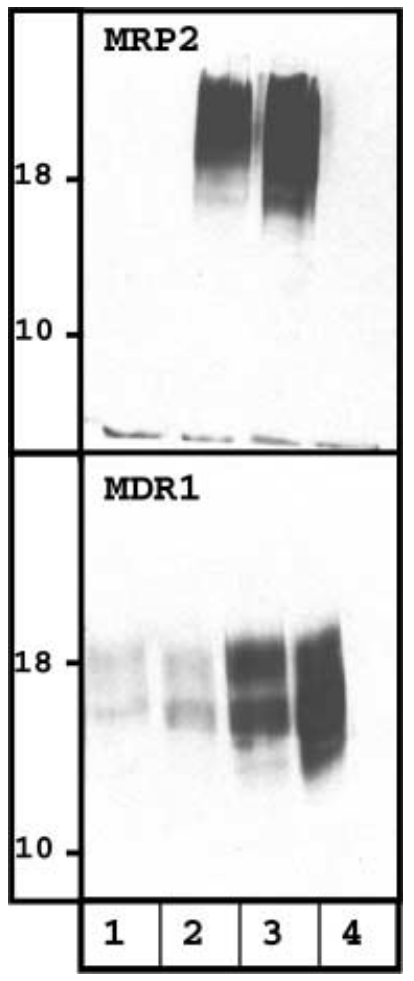

in the two MDCK-MRP2 lines. From the fact that the "active" MDCK-MRP2 contained far higher levels of Mdr1 signal than the "inactive" MDCK-MRP2 cells but showed no difference in MRP2, we conclude that the endogenous Mdr1 Pgp was responsible for the high capacity to translocate $\mathrm{C}_{6}$-NBD-GlcCer. The upregulated expression of endogenous Mdr1 Pgp also explains that $\mathrm{C}_{6}$ NBD-PC and $\mathrm{C}_{6}$-NBD-PE were translocated, that translocation was sensitive to MDR1 inhibitors but not to an MRP1 inhibitor, and that translocation was insensitive to glutathione depletion.

\section{Summarizing remarks}

One accepted approach in the field of transporter function is the expression or overexpression of a specific transport protein in a cell line with a low background of the endogenous protein. The assumption in such an approach is that the expression of the endogenous protein remains low during the transfection procedure and that the activity of the protein under study can be characterized by comparing transport in the transfected cells to that in mock-transfected controls. This approach has been validated by our characterization of the lipid substrate specificity of the ABC transporters MDR3 Pgp, MDR1 Pgp, and MRP1 using pig kidney-derived LLC PK1 cells as host cells (van Helvoort et al. 1996; Raggers et al. 1999). However, in the present study we report upregulation of the expression of Mdr1 Pgp in an MDCK II cell line that had been transfected with MRP2. Without proper controls, we might have assigned proper- 
ties to MRP2 that actually reside in the endogenous Mdr1 Pgp.

Acknowledgements We are grateful to Wil Lieftink for technical assistance during the experiments and for expert cell culture. This work was supported by the Netherlands Foundation for Chemical Research (NWO-CW) with financial aid from the Netherlands Organization for Scientific Research.

\section{References}

Bakos E, Evers R, Sinko E, Varadi A, Borst P, Sarkadi B (2000) Interactions of the human multidrug resistance proteins MRP1 and MRP2 with organic anions. Mol Pharmacol 57:760-768

Borst P, Zelcer N, Helvoort A van (2000) ABC transporters in lipid transport. Biochim Biophys Acta 1486:128-144

Bosch I, Dunussi-Joannopoulos K, Wu R-L, Furlong ST, Croop J (1997) Phosphatidylcholine and phosphatidylethanolamine behave as substrates of the human MDR1 P-glycoprotein. Biochemistry 36:5685-5694

Evers R, Cnubben NH, Wijnholds J, Deemter L van, Bladeren PJ van, Borst P (1997) Transport of glutathione prostaglandin A conjugates by the multidrug resistance protein 1 . FEBS Lett 419:112-116

Evers R, Kool M, Deemter L van, Janssen H, Calafat J, Oomen LCJM, Paulusma CC, Oude Elferink RPJ, Baas F, Schinkel AH, Borst P (1998) Drug export activity of the human canalicular multispecific organic anion transporter in polarized kidney MDCK cells expressing cMOAT (MRP2) cDNA. J Clin Invest 101:1310-1319

Evers R, Haas M de, Sparidans R, Beijnen J, Wielinga PR, Lankelma J, Borst P (2000) Vinblastine and sulfinpyrazone export by the multidrug resistance protein MRP2 is associated with glutathione export. Br J Cancer 83:375-383

Farge E, Ojcius DM, Subtil A, Dautry-Varsat A (1999) Enhancement of endocytosis due to aminophospholipid transport across the plasma membrane of living cells. Am J Physiol 276:C725-C733

Gottesman MM, Pastan I (1993) Biochemistry of multidrug resistance mediated by the multidrug transporter. Annu Rev Biochem 62:385-427
Haila S, Saarialho-Kere U, Karjalainen-Lindsberg M-J, Lohi H, Airola K, Holmberg C, Hästbacka J, Kere J, Höglund P (2000) The congenital chloride diarrhea gene is expressed in seminal vesicle, sweat gland, inflammatory colon epithelium, and in some dysplastic colon cells. Histochem Cell Biol 113:279286

Helvoort A van, Hof W van 't, Ritsema T, Sandra A, Meer G van (1994) Conversion of diacylglycerol to phosphatidylcholine on the basolateral surface of epithelial (Madin-Darby canine kidney) cells. Evidence for the reverse action of a sphingomyelin synthase. J Biol Chem 269:1763-1769

Helvoort A van, Smith AJ, Sprong H, Fritzsche I, Schinkel AH, Borst P, Meer G van (1996) MDR1 P-glycoprotein is a lipid translocase of broad specificity, while MDR3 P-glycoprotein specifically translocates phosphatidylcholine. Cell 87:507517

Jeckel D, Karrenbauer A, Burger KNJ, Meer G van, Wieland F (1992) Glucosylceramide is synthesized at the cytosolic surface of various Golgi subfractions. J Cell Biol 117:259-267

Keppler D, Leier I, Jedlitschky G (1997) Transport of glutathione conjugates and glucuronides by the multidrug resistance proteins MRP1 and MRP2. Biol Chem 378:787-791

Paulusma CC, Bosma PJ, Zaman GJ, Bakker CT, Otter M, Scheffer GL, Scheper RJ, Borst P, Oude Elferink RP (1996) Congenital jaundice in rats with a mutation in a multidrug resistance-associated protein gene. Science 271:1126-1128

Pomorski T, Herrmann A, Muller P, Meer G van, Burger K, (1999) Protein-mediated inward translocation of phospholipids occurs in both the apical and basolateral plasma membrane domains of epithelial cells. Biochemistry 38:142-150

Raggers RJ, Helvoort A van, Evers R, Meer G van (1999) The human multidrug resistance protein MRP1 translocates sphingolipid analogs across the plasma membrane. J Cell Sci 112:415-422

Raggers RJ, Pomorski T, Holthuis JCM, Kaelin N, Meer G van (2000) Lipid traffic: the ABC of transbilayer movement. Traffic 1:226-234

Sugawara-Yokoo M, Urakami Y, Koyama H, Fujikura K, Masuda S, Saito H, Naruse T, Inui K, Takata K (2000) Differential localization of organic cation transporters rOCT1 and rOCT2 in the basolateral membrane of rat kidney proximal tubules. Histochem Cell Biol 114:175-180 